Portland State University

PDXScholar

TREC Final Reports

Transportation Research and Education Center

(TREC)

$2-2010$

Bicycle and Pedestrian Design Curriculum Expansion

Lynn Weigand

Portland State University

Follow this and additional works at: https://pdxscholar.library.pdx.edu/trec_reports

Part of the Transportation Commons, and the Urban Studies and Planning Commons

Let us know how access to this document benefits you.

Recommended Citation

Weigand, Lynn. Bicycle and Pedestrian Design Curriculum Expansion. OTREC-ED-10-01. Portland, OR:

Transportation Research and Education Center (TREC), 2010. https://doi.org/10.15760/trec.11

This Report is brought to you for free and open access. It has been accepted for inclusion in TREC Final Reports by an authorized administrator of PDXScholar. Please contact us if we can make this document more accessible: pdxscholar@pdx.edu. 


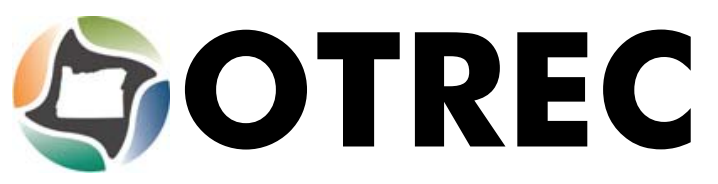

FINAL REPORT

\section{Bicycle and Pedestrian Design Curriculum Expansion}

OTREC-ED-10-01 January 2010 



\section{BICYCLE AND PEDESTRIAN DESIGN CURRICULUM EXPANSION}

\section{Final Report}

OTREC-ED-10-01

by

Lynn Weigand, Ph.D.

Portland State University

for

Oregon Transportation Research and Education Consortium (OTREC)

P.O. Box 751

Portland, OR 97207

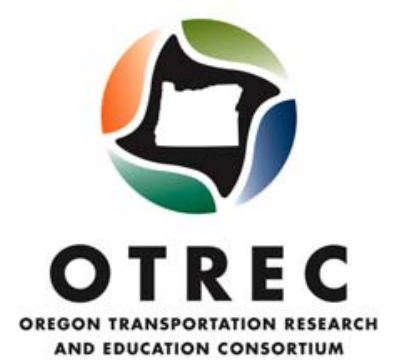

February 2010 



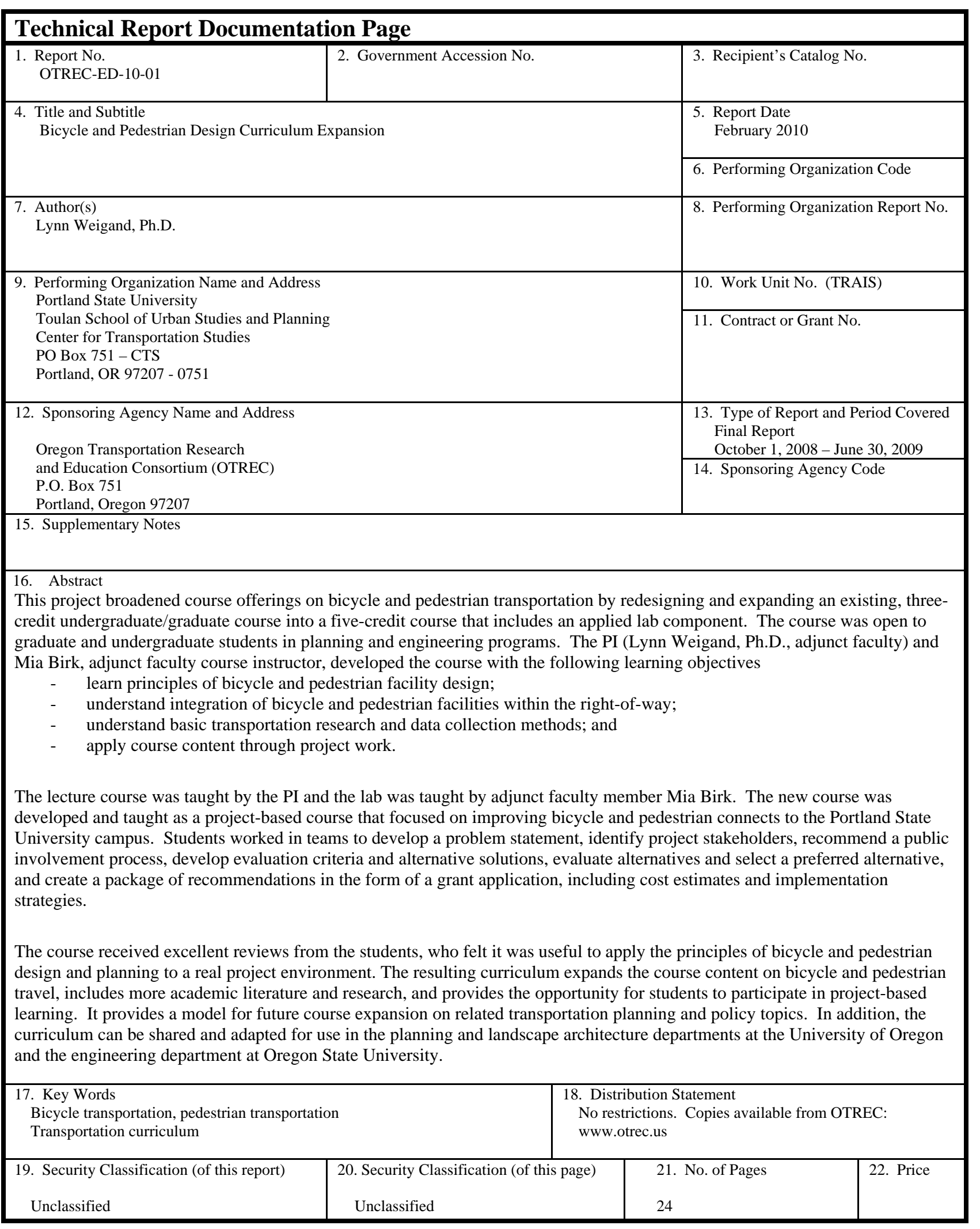





\section{ACKNOWLEDGEMENTS}

This project was funded by the Oregon Transportation Research and Education Consortium (OTREC).

\section{DISCLAIMER}

The contents of this report reflect the views of the authors, who are solely responsible for the facts and the accuracy of the material and information presented herein. This document is disseminated under the sponsorship of the U.S. Department of Transportation University Transportation Centers Program and the Oregon Transportation Research and Education Consortium (OTREC) in the interest of information exchange. The U.S. Government and OTREC assume no liability for the contents or use thereof. The contents do not necessarily reflect the official views of the U.S. Government or OTREC. This report does not constitute a standard, specification, or regulation. 



\section{TABLE OF CONTENTS}

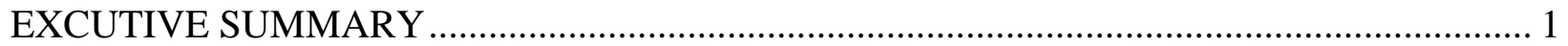

1.0 BACKGROUND AND OBJECTIVES ................................................................. 3

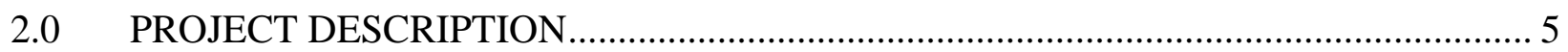

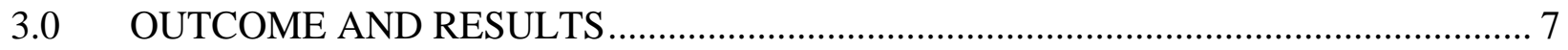

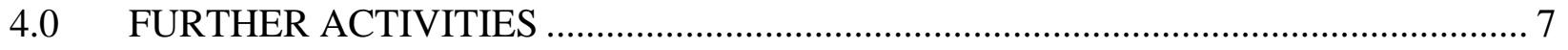

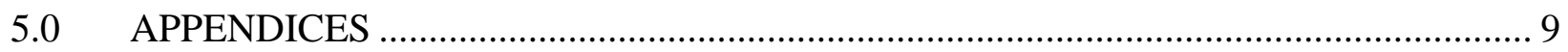

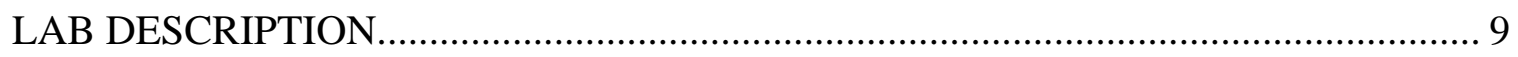

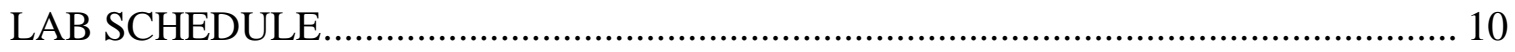

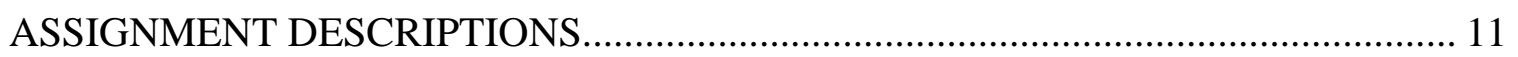

GRANT APPLICATION INSTRUCTIONS \& FORM ................................................ 11 



\section{EXCUTIVE SUMMARY}

This project broadened course offerings on bicycle and pedestrian transportation by redesigning and expanding an existing, three-credit undergraduate/graduate course into a five-credit course that includes an applied lab component. The course was open to graduate and undergraduate students in planning and engineering programs. The PI (Lynn Weigand, Ph.D., adjunct faculty) and Mia Birk, adjunct faculty course instructor, developed the course with the following learning objectives

- $\quad$ learn principles of bicycle and pedestrian facility design;

- $\quad$ understand integration of bicycle and pedestrian facilities within the right-of-way;

- understand basic transportation research and data collection methods;

- apply course content through project work;

The lecture course was taught by the PI and the lab was taught by adjunct faculty member Mia Birk. The new course was developed and taught as a project-based course that focused on improving bicycle and pedestrian connects to the Portland State University campus. Students worked in teams to develop a problem statement, identify project stakeholders, recommend a public involvement process, develop evaluation criteria and alternative solutions, evaluate alternatives and select a preferred alternative, and create a package of recommendations in the form of a grant application, including cost estimates and implementation strategies.

The course received excellent reviews from the students, who felt it was useful to apply the principles of bicycle and pedestrian design and planning to a real project environment. The resulting curriculum expands the course content on bicycle and pedestrian travel, includes more academic literature and research, and provides the opportunity for students to participate in project-based learning. It provides a model for future course expansion on related transportation planning and policy topics. In addition, the curriculum can be shared and adapted for use in the planning and landscape architecture departments at the University of Oregon and the engineering department at Oregon State University. 


\subsection{BACKGROUND AND OBJECTIVES}

Nationwide, few courses are offered that focus specifically on design for pedestrian and bicycle facilities. Portland State University has only one, three-credit course on the subject, which does not provide adequate opportunity to cover bicycle and pedestrian transportation planning, policy, design and practice. The existing course has been a useful introduction to the topic and has received excellent reviews for the past five years. However, faculty saw a need to expand the curriculum, increase the academic rigor, expose the students to more of the current research in the field, and enhance the application of knowledge through a practice-based field project.

The goal of this project was to broaden course offerings on bicycle and pedestrian transportation by redesigning and expanding an existing, three-credit undergraduate/graduate course into a fivecredit course that includes an applied lab component. The course was open to graduate and undergraduate students in planning and engineering programs. The PI (Lynn Weigand, Ph.D., adjunct faculty) and Mia Birk, adjunct faculty course instructor, developed the course with the following learning objectives

- learn principles of bicycle and pedestrian facility design;

- $\quad$ understand integration of bicycle and pedestrian facilities within the right-of-way;

- $\quad$ understand basic transportation research and data collection methods; and

- apply course content through project work. 


\subsection{PROJECT DESCRIPTION}

The lecture course was taught by the PI (Lynn Weigand, Ph.D., adjunct faculty) and the lab was taught by adjunct faculty member Mia Birk. They worked together to develop the new course, which included:

- evaluating the existing course content and identifying gaps;

- developing an outline of new course material;

- refining the course learning objectives;

- developing a new course outline;

- researching and selecting resource/reading materials;

- researching and scheduling appropriate guest lecturers;

- creating course assignments and project; and

- developing student and course evaluation methods and criteria.

The new course was developed and taught as a project-based course that focused on improving bicycle and pedestrian connects to the Portland State University campus. A total of 17 students were enrolled in the class (ten graduate and seven undergraduate), and were required to take the three-credit lecture course concurrently. PSU's Transportation Options Coordinator Ian Stude led campus tours on bicycle for the students and shared information gained through survey work. Students also worked with Portland Office of Transportation (PDOT) Transportation Assistant David Amiton to conduct bike counts that were later provided to PDOT for their bike count database.

Students worked in teams to develop a problem statement, identify project stakeholders, recommend a public involvement process, develop evaluation criteria and alternative solutions, evaluate alternatives and select a preferred alternative, and create a package of recommendations in the form of a grant application, including cost estimates and implementation strategies.

Specifically, the student teams were required to complete the following tasks:

- Develop a problem statement. Concepts of problems statements and how to write them were discussed in class. Students were requested to submit and revise their problem statements to use objective language and submit a letter of intent.

- Identify project stakeholders and recommend a public involvement process.

- Collect data on existing conditions including traffic volumes, speed, crash histories, street classifications, relevant plans and policies, planned land uses and field data (such as opportunities and constraints, parking, traffic patterns, land uses, field conditions, barriers, turn movements, access needs) and Students were required to summarize their findings in an existing conditions report and present their findings in class during an open discussion. 
- Create legible maps to convey complex information. Students were invited to visit with designers and planners at Adjunct Professor Birk's firm (Alta Planning + Design) to review draft maps, and get advice on how to convey the information in a graphical format and their proposed design concepts.

- Develop criteria to use in evaluating alternatives and selecting a preferred alternative. Students considered the range of stakeholders and needs to develop evaluation criteria.

- Develop alternative solutions and evaluate them using the established criteria. Students brainstormed the universe of alternatives and discussed trade-offs, such as impacts on bicyclist safety and comfort, pedestrian safety and comfort, access to businesses, parking, traffic circulation and transit access in evaluating alternatives. They used the criteria to evaluate alternatives then selected preferred alternatives for their final recommendations. They also discussed liability issues and trade-offs required for their recommendations and worked in class with the instructor and PSU's Transportation Coordinate Ian Stude to refine their recommendations.

- Develop final recommendation packages. Students developed a package of recommendations including maps, illustrations and cost estimates based on unit costs provided by Adjunct Professor Birk.

- Present recommendations. The student teams presented their their recommendations to a review "board" with Roger Geller, City of Portland Bicycle Coordinator; Lidwien Rahman, Oregon Department of Transportation \& Willamette Pedestrian Coalition; Ian Stude, PSU Transportation Coordinator; and Lynn Weigand, Director, Initiative for Bicycle and Pedestrian Innovation and Co-PI. 


\subsection{OUTCOME AND RESULTS}

The final projects demonstrated student knowledge and ability to apply bicycle and pedestrian planning and design principles to a real project scenario. The project recommendations were of high quality and have the potential for implementation. One undergraduate student is taking the final projects and packaging them into a single report that will be presented at the City's Bicycle Advisory Committee meeting in January, and brought forward into the City's Platinum Bicycle Master Plan.

The course received excellent reviews from the students, who felt it was useful to apply the principles of bicycle and pedestrian design and planning to a real project environment. A summary of the course evaluation is located in Appendix B. Given the positive feedback from the instructor and student experience, the Co-PI will recommend that this course be offered each year with the potential to be added to the department's transportation planning curriculum.

The materials developed for this project expand the course content on bicycle and pedestrian travel and provide the opportunity for students to participate in project-based learning. This gives the students valuable experience in applying theory, design and planning principles to transportation planning issues which is useful preparation for professional positions in public and private sector planning.

The value of the course was recognized by the department which chose to offer it again during fall term 2009.

\subsection{FURTHER ACTIVITIES}

The curriculum provides a model for future course expansion on related transportation planning and policy topics. In addition, the curriculum can be shared and adapted for use in the planning and landscape architecture departments at the University of Oregon and the engineering department at Oregon State University. The course outline is available on IBPI's website. 


\subsection{APPENDICES}

Pedestrian \& Bicycle Planning Lab

USP 510 (Lab for USP 465/565)

Mondays 10:00-11:50 am

Fall Quarter 2008

ROOM: URBN 220

Instructor: Mia L. Birk, mbirk@pdx.edu, 503-880-8615

PSU Transportation Options Coordinator: Ian Stude, 503-725-9015, istude@pdx.edu

\section{LAB DESCRIPTION}

This course provides an opportunity to apply the principles and techniques of bicycle and pedestrian planning and design to real-world applications. Students will be challenged to improve conditions for these modes and integrate them into an existing transportation network by completing a comprehensive planning project for a location near or within the Portland State University campus. Since writing grant applications is an integral part of funding bicycle and pedestrian projects, students will use a mock grant application process to identify a bicycle or pedestrian-related access issue and develop a solution.

The lab will be conducted as a studio course, with hands-on work occurring during class time, as well as out of class. The instructor and guest practitioners will work closely with the students through each phase of the project development.

The focus of the lab is on improving bicycle and pedestrian access to PSU. Students will work in teams of three to five students on one of four areas:

- Access from the south $\left(4^{\text {th }} \& 6^{\text {th }}\right.$, crossing I-405)

- Access from the Hawthorne Bridge

- Access from NW (south of Burnside, east of $18^{\text {th }}$ ), including the SW corner of campus

- Access from the north (Broadway, $5^{\text {th }}$, and the Park Blocks).

All parts of the grant application must be completed in order to receive credit. Incomplete applications will not be accepted.

Original Research: Students may not select a location which they have already researched, presented, or that they are working on for another class. Note that this includes locations or improvements selected for the Innovative Design assignment in the lecture portion of this course. Final Report: Students will be provided with sample grant applications. Grant format and requirements follow below. While students are not expected to be professional layout artists or graphics experts, materials submitted should be neat and professionally presented. Graduate students will also be required to present a 10 minute overview of their project during the final lab period. 
Group Work: In the "real world" effectively working in groups is essential to your success. All assignments for this lab will be completed in groups. Group members will be allowed the opportunity to review the contribution of their team members.

\section{LAB SCHEDULE}

\begin{tabular}{|c|c|c|c|}
\hline Class & Date & Topic & Assignments Due \\
\hline 1 & $9 / 29$ & $\begin{array}{l}\text { Introduction, overview of course, } \\
\text { mapping of access issues. Guest: } \\
\text { Ian Stude, PSU Transportation \& } \\
\text { Parking Services. }\end{array}$ & \\
\hline 2 & $10 / 6$ & $\begin{array}{l}\text { Fieldwork - Ian Stude to lead bike } \\
\text { ride to review field conditions. } \\
\text { Students to map their findings in } \\
\text { terms of issues and opportunities }\end{array}$ & \\
\hline 3 & 10/13 & $\begin{array}{l}\text { In-class work on problem } \\
\text { statements, data collection, and } \\
\text { stakeholder identification }\end{array}$ & Problem statement/ \\
\hline 4 & $10 / 20$ & Fieldwork & Letter of Intent \\
\hline 5 & $10 / 27$ & $\begin{array}{l}\text { Report/discussion on observations } \\
\text { and progress }\end{array}$ & Data collection memc \\
\hline 6 & $11 / 3$ & $\begin{array}{l}\text { Development of selection criteria } \\
\text { and alternatives. In-class } \\
\text { exercises. }\end{array}$ & \\
\hline 7 & $11 / 10$ & Analysis of alternatives & \\
\hline 8 & 11/17 & $\begin{array}{l}\text { Technical analysis of project } \\
\text { benefits }\end{array}$ & \\
\hline No Class & $11 / 24$ & $\begin{array}{l}\text { Happy Thanksgiving! Work on } \\
\text { projects. }\end{array}$ & \\
\hline 9 & $12 / 1$ & $\begin{array}{l}\text { Final Presentations - Graduate } \\
\text { Students Only }\end{array}$ & $\begin{array}{l}\text { Final Report \& } \\
\text { Graduate Student } \\
\text { Presentation }\end{array}$ \\
\hline 10 & $12 / 8$ & Finals Week - No Lab & \\
\hline
\end{tabular}


10 Points Problem Statement/Letter of Intent - This will be a 1-2 page synopsis with a problem statement, project history or research history, and intended outcome of the project.

No points Data Collection Memo - This will be a 1 page synopsis of the data you will need and the potential sources for that data.

15 Points Alternatives: Opportunities \& Constraints Memo - This will be a 2-3 page analysis of the selected alternatives in terms of costs and funding, construction feasibility and impact, and effectiveness of the proposed solution (Does the improvement create new issues? e.g., ADA access for elevated pedestrian crossing). Are there any additional opportunities or constraints?

50 Points Final Report- The final report will consist of the completed grant application package.

25 Points Presentations - Graduate students will also be required to prepare a 10 minute presentation in either PowerPoint, presentation boards, or other presentation manner.

Total: 100 Points

\section{GRANT APPLICATION INSTRUCTIONS \& FORM}

\section{Select a grant topic per previous instructions.}

- There must be a bicycle or pedestrian-related problem in order to have a solution.

- You must be able to analyze and quantify the potential costs and benefits.

- You will need to research the topic, understand/explain the process by which you propose to solve the problem, and illustrate clearly proposed solutions.

- This must be original research. 


\section{GRANT APPLICATION FORM}

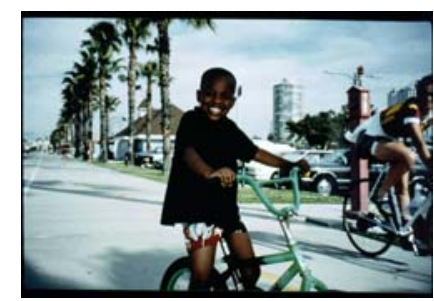

Total application package: 25 pages max.

1. Cover Sheet

2. Project/Program Title:

a. Lead Agency (i.e., entity or agency that would be responsible for match):

b. Your Name:

\section{Project Cost/Requested Funds}

\begin{tabular}{|l|l|}
\hline $\begin{array}{l}\text { Funds } \\
\text { requested }\end{array}$ & $\$$ \\
\hline $\begin{array}{l}\text { Proposed } \\
\text { match }\end{array}$ & $\$$ \\
\hline TOTAL & $\$$ \\
\hline
\end{tabular}

Please provide detailed cost estimate with a breakdown of costs, including staff hours broken down by task, design, and installation/construction costs as well as any supporting details. Maximum grant amount is $\$ 500,000$. Insert a table with specific costs and explain any assumptions you have made about phasing, costs, etc...

4. Project/Program Description (up to 10 pages).

a. Explain the current transportation problem and how the nominated project would address the problem. Include any specific safety or other data, studies, or criteria that help make your case.

b. Attach vicinity map(s) indicating project location and relevant features.

c. Include street or facility termini (if applicable) or project boundaries, and physical description of the main project features (e.g., length, number and width of lanes, bike lanes and/or sidewalks, bridge crossings, medians, planting strip, etc.). Be specific as to your design dimensions, and make sure they comply with current standards. Specify which standards on which you are basing your design.

d. Provide digital photo(s) of the project. Illustrate either by hand, by Photoshop rendering, or another computer graphics program what your proposed project will achieve. Provide enough detail to be clear as to your vision.

e. What other alternatives (route or design) did you consider? How did you decide which alternative you selected (e.g. what were your selection criteria and how did you apply them)?

f. What are the trade-offs involved in your solution, and why is solution the best one? 
5. Potential Project Benefits (up to 5 pages)

a. Complete a numerical evaluation of the potential project use, using a latent demand analysis or other method as we have discussed in class. Explain your methodology.

b. Estimate or describe potential air quality, safety, land-use, or other technical or community benefits.

6. Project Process. Explain what process you will use to ensure that your project is implemented. (up to 5 pages) Include:

a. What studies, policies, or relevant documents or planning efforts help bolster this project? Summarize in sufficient detail.

b. Discuss your outreach process for reaching consensus. Who are the involved stakeholders? What kind of consensus-building process would you use? 


\section{USP 410-510: Sustainable Transportation Lab}

\section{GENERAL}

1. There was an adequate relationship between the material

Strongly presented in the lecture course (USP 465/565) and the project work in this course.

2. It was useful to take both the lecture course and the lab.
Agree

5

5
Strongly

Neutral Disagree

$\begin{array}{llll}4 & 3 & 2 & 1\end{array}$

$\begin{array}{lllll}5 & 3 & 2 & 1\end{array}$

\section{PROJ ECT}

3. The project experience was useful and applicable

$\begin{array}{lll}4 & 3 & 2\end{array}$

1

4. What elements did you like or find most useful about the project experience?

5. What, if any, elements would you change about the project experience?

6. Please rank the usefulness and relevancy of the project to your learning experience

$\begin{array}{ccccc}\text { Very Useful } & & \text { Neutral } & & \text { Not Useful } \\ 5 & 4 & 3 & 2 & 1\end{array}$

7. Please tell us how the project helped you understand concepts of bicycle and pedestrian planning and design:

\section{N-CLASS EXERCI SES}

8. How helpful were the following in-class activities?

$$
\text { Very Helpful Neutral Not Helpful }
$$

a. Problem Statement Development

b. Street Cross-Section Exercise

5

c. Selection Criteria

5

5

d. Visit to Adjunct Professor Birk’s office

5

4

3

2

9. Any other comments or suggestions? 


\section{USP 410-510 Summary of Evaluations - Fall 2008}

1. There was an adequate relationship between the material presented in the lecture course (USP 465/565) and the project work in this course.

$\begin{array}{lllll}\underline{5} & \underline{4} & \underline{3} & \underline{2} & \underline{1}\end{array}$

$6 \quad 6 \quad 2$

Average

$2 \quad 4.2$

2. It was useful to take both the lecture course and the lab

$\begin{array}{lllll}\underline{5} & \underline{4} & \underline{3} & \underline{2} & \underline{1} \\ 9 & 3 & 2 & \end{array}$

3. The project experience was useful and applicable

$\begin{array}{lllll}\underline{5} & \underline{4} & \underline{3} & \underline{2} & \underline{1}\end{array}$

103

4. What elements did you like or find most useful about the project experience?

The field work and the garnering of knowledge about how to put a grant relating to bike-specific issues together

A more in-depth look at one part of town. Lots more evaluation of alternatives.

Local application; Interesting mix of problems to solve; done in city that doesn't require MUTCD adherence; client available and enthusiastic; relevant

I liked learning and practicing the key elements of great propsal writing, which are very different than academic writing - clarity, focus, strong arguments, etc.

Challenging my planning concepts

Fieldwork; grant application

Working with planners at Alta

Application of design principles/guidelines to a real project environment. Simply having a platform for this work is highly useful.

Taking pictures.

It is an opportunity to gain "real" experience as opposed to just listening to theories and presentations.

Good exposure to new methods of analysis, BQL, etc.

Learning the steps in the planning

process 


\section{What, if any, elements would you change about the project experience?}

More in class fieldwork if possible. I would have liked to better understand mapping nad displaying info graphically.

Some more guidance on steps along the process for our project.

Meetings with instructor for each group to check in.

More focus on doing work in the lab. (it's not a lecture.)

Shorter

Emphasize constructing project teams with a variety of skill sets (i.e. graphics)

\section{Please rank the usefulness and relevancy of the project to your learning experience}

$\begin{array}{rrrrrr}\underline{\mathbf{5}} & \underline{\mathbf{4}} & \underline{\mathbf{3}} & \mathbf{2} & \underline{\mathbf{1}} & \text { Average } \\ 11 & 2 & & & & \end{array}$

\section{Please tell us how the project helped you understand the concepts "bicycle and pedestrian planning and design"}

I started at very little experience with issues, and feel that I have much greater knowledge regarding what it takes to design and implement bike and ped infrastructure.

Chance to apply possible solutions to real world situations. PSU needs better bike connections. Very relevant to our lives as students and cyclists.

We learned the basics. I'm so excited that 20-30 planners and engineers take this class every year, because I know I'll be able to ride on much better facilities in 5-10 years.

Made me engage fully in the principles learned in 465 and think about practical applications.

Hands-on application

Provided hands-on experience with the planning process

Concepts became clear when applied to a site. Real life design constraints promote critical thinking and working solutions.

Trade-offs

It was helpful to be provided with real examples of each element (e.g. from an Alta project) to help pmodel the grant project.

Understanding that there is a process and it is detailed, documenting the process, looking at past experience, etc.

Improved sense of how to apply and integrate design standards and theory from lecture class The level of detail in decision making has reached new heights for me 


\section{How helpful were the following in-class activities?}

$\begin{array}{lllll}\underline{5} & \underline{4} & \underline{3} & \underline{2} & \underline{1}\end{array}$

a. Problem

Statement

Development

$6 \quad 6 \quad 1$

Average

4.38

b. Street

Cross-

Section

Exercise

6

5

2

4.3

c. Selection

Criteria

5

5

2

1

4.08

d. Visit to

Prof. Birk's

office

9

3

1

\section{Any other comments or suggestions?}

Thanks.

Should be kept as optional lab. Great insight to professional realm from Prof. Birk

Videotape the class, post it online so it can be used as a resource for people elsewhere.

This class was extremely frustrating to me at first - I had no experience with bike planning and felt out of my element. I feel like I have been given good tools to make this project happen, and it has definitely pushed my boundaries.

I wish there was more time spent in the lab sessions working on specifics of each project/problem. There were numerous missed opportunities to work together on technical design details and process.

Prof. Birk's stories about her work have been very helpful and educational. For 2 credits this project seems way too big.

Re-sequence lecture course to cover concepts needed for lab earlier on

Offer more courses like this 



\section{AOTREC \\ OREGON TRANSPORTATION RESEARCH \\ AND EDUCATION CONSORTIUM}

\section{P.O. Box 751}

Portland, OR 97207

OTREC is dedicated to stimulating and conducting collaborative multi-disciplinary research on multi-modal surface transportation issues, educating a diverse array of current practitioners and future leaders in the transportation field, and encouraging implementation of relevant research results. 